\title{
Content Validity of West African Examination Council Financial Accounting Questions
}

\author{
Basil C. E Oguguo, John J. Agah and Catherine U. Ene \\ Department of Science Education, University of Nigeria Nsukka, Nigeria \\ https://orcid.org/0000-0002-0723-2248 \\ https://orcid.org/0000-0001-9076-0887 \\ https://orcid.org/0000-0001-5837-2147 \\ Vivian N. ACholonu \\ Department of life Science Education, Imo State University, Nigeria \\ https://orcid.org/0000-0002-6497-9460 \\ Roseline N. Azubuike* \\ Department of Business Education, University of Nigeria Nsukka, Nigeria \\ https://orcid.org/0000-0003-2647-2420 \\ Mary A. Okeke and Lourita P. Agbo \\ Department of Science Education, University of Nigeria Nsukka, Nigeria \\ https://orcid.org/0000-0001-9950-8039 \\ https://orcid.org/0000-0002-4209-6667
}

\begin{abstract}
The study sought to ascertain the content validity of West African Examination Council Multiple-Choice Test Items in Financial Accounting from 2016-2018. The researchers assessed how spread taxonomically the content of the core curriculum in the WASSCE Financial Accounting questions were. The population of the study included all the West African Senior School Certificate Examination (WASSCE) multiple-choice question papers in Financial Accounting set by the Council. The sample covered multiple-choice test items from 2016-2018. Two research questions and two hypotheses guided the study. The Financial Accounting curriculum and the WASSCE Financial Accounting questions were the main instruments used for data collection. A total of 150 WASSCE objective questions papers were categorized in line with the various cognitive levels. The results revealed that some topics were overemphasized while others were underemphasized. Some topics like introduction to accounting were ignored. The spread of the questions to different cognitive levels did not comply with the required standard; therefore, the WASSCE questions within the period have low content validity. The curriculum should
\end{abstract}

\footnotetext{
* Corresponding author: Roseline N. Azubuike, Email: roseline.azubuike@unn.edu.ng
} 
from time-to-time be scrutinized alongside the WASSCE syllabus in order to make the two agree in both content and objectives.

Keywords: content validity; curriculum validity; examination; multiplechoice tests; financial accounting

\section{Introduction}

The Nigerian system of Education has gone through tremendous changes and innovations over the years. These changes were targeted towards achieving the educational goals set by the government in power. At the junior level, the curriculum design adopted is mainly the broad field design; though some subjects were taught as compartmentalized disciplines such as Igbo language, Home Economics and Mathematics, et cetera. Some other subjects related are organized in broad or large fields such as Commerce, Book-keeping, Shorthand and Economics which were all integrated to form Business Studies. Also, Biology, Physics and Chemistry were organized to form Integrated Science at the Junior Secondary School level. This is the case with some other subjects at the Senior Secondary School level. A close look at the National curriculum will reveal that the design adopted at the senior secondary level is subject-centered curriculum.

The recently introduced 9-3-4 government policy in education in Nigeria requires a child to complete a nine-year basic education at the age of 14 to 15 years before proceeding to a three-year secondary education. In the view of Oparaku (2005), the three-year secondary education terminates after the students must have written the West African Senior School Certificate Examination (WASSCE) which is presently conducted in Nigeria by the West African Examination Council (WAEC). WASSCE is among the standardized examinations in Nigeria by which students are assessed to ascertain how much they have achieved after being exposed to the secondary school curricula (Adewuyi \& Oluokun, 2001).

The WAEC is a Board established by law to determine; the examinations required in the public interest of the English-speaking West African countries, to conduct examinations and to award certificates that are comparable to those of other equivalent examining authorities internationally. The board was established in 1952, and since then, the council has contributed to education in Anglophonic countries in West Africa (Ghana, Nigeria, Sierra Leone, Liberia, and Gambia) based on the numbers of examinations they have coordinated and the certificates they have issued. The Board also founded an endowment fund that is responsible for contributing to educations in West Africa with the help of lectures and provisions of aids to those who cannot afford education (Akinbolati, 2003). The Board is responsible for conducting four different categories of examinations; these are International Examinations, National Examinations, Examinations conducted in collaboration with other examining bodies, and Examinations conducted on behalf of other examining bodies. The International examinations imply the examinations written in the five countries 
with the WAEC ordinance. These include West African Senior School Certificate Examination (WASSCE) that is administered as follows:

- WASSCE for private candidates (first series) January-February

- WASSCE for (School Candidates) March - May

- WASSCE for private Candidates (Main GCE) September-October

The National Examinations are written in each country; and Financial Accounting is one of the subjects undertaken by students at the senior secondary school level. Nevertheless, Alimi, Ehinola and Alabi (2012) opined that there is low level of enrolment of students in this subject in the senior school examinations conducted by West African Examination Council in Nigeria. Financial Accounting has been defined by many authorities. Okereke (2000) referred to Financial Accounting as the collection, review and adjustment of financial data for the main purpose of presenting final Accounts (income statements, sources and uses of funds statements and Balance Sheet).

Many people mistake Financial Accounting for Book-keeping which is referred to as the act of recording business activities or transactions in an orderly manner in order to enable the books show at any time the financial position of the business. According to Eneja (2013), the concept of Book-keeping is smaller; as a result, it can be referred to as a unit or branch of Financial Accounting. Accounting is concerned with the acquisition of knowledge for recording, analyzing, interpreting and summarizing the financial data of an organization or enterprise (Obidile, Amobi, Uzoekwe \& Akuezilo, 2017). Amadi (2002) stated that financial accounting is that branch of business accounting that deals with the collection, accumulation, adjustment and presentation of financial information for the use of both internal and external parties. Financial Accounting, as earlier mentioned constitutes part of subjects offered at the senior secondary schools; it has a curriculum that has been designed to specify the contents and behavioral objectives needed to equip one for efficient financial management ability. Asaolu (2002) defined Accounting from a traditional perspective, the author sees the subject as the process of collecting, analyzing, interpreting and communicating the financial information of a business. The traditional perspective view of accounting as a mechanical process that does not interact much with the business environment as opined by Chinweike (2011). On the other hand, Chinweike (2011) using modern business perspective views financial accounting as a lens through which makers sees through the clouded business world. This is to say that accounting has seized to be an almost automated process that it used to be and is now highly scalable; by scalable, it means that accounting process is now robust enough to accommodate any unforeseen event that turns out. The learning of the subject offers one the opportunity of becoming an accountant and financial expert in the financial market (Bob, 2012).

Financial Accounting topics are designed very well according to their importance. From the weights attached to them, one who acquires the theoretical aspect in school should be able to fit into different aspects of life. Since the senior school certificate is an essential requirement for academic advancement and 
employment; it is therefore, pertinent to ascertain the content validity of the test instrument of WAEC as one of the bodies saddled with the responsibility of conducting senior school certificate examination in various subject areas which equally includes Financial Accounting (Igben, 2009). The Federal Republic of Nigeria in her National Policy on Education (2004) stipulate that financial accounting is an elective course in the senior secondary schools while the Nigerian Educational Research and Development Council NERDC (2007) summarized the objectives of studying the subject in secondary schools to: equip secondary school students with the necessary knowledge about the various reforms; changes and adjustments in the country's economic and financial system; to enable secondary school students understand the rudiments and fundamentals of the Nigerian financial system and the public sector accounting; which will inculcate in them the spirit of transparency and accountability in public financial management; and to inculcate the interest and the needed foundation in the students that will encourage them to become professionally qualified accountants (Uwameiye \& Ogunbameru, 2005).

A test can be defined as an instrument of measurement which connotes a structured situation comprising a set of questions administered to an individual to respond to from which his behaviors or traits are quantified. According to Donna (2011), examination is a deliberate attempt at obtaining a sample of one's behaviour, knowledge, skills and ability or performance in a particular field of study, verbally, in written form or in a practical term. Achievement in the school context is seen as an increase in knowledge, skills and dispositions the learner acquired from exposure, teaching and instruction as opposed to the endowment inheritance (Illeris, 2014). It is concerned with the mastery of the general or specific knowledge areas to which the teacher exposes his learners. Examination means different things to different people; some sees it as a true test of knowledge others as an entrustment of social discrimination whereby the less fortunate feels inferior to the more privileged. As of today, it is believed, that there is no better index for evaluating students' achievement in school. Therefore, examination is an integral part of our educational system. The results of examinations are used for placement, selection, promotion and certification.

Nigeria, seeing the enviable positions of some countries like America, Germany, Britain, France, Australia and even some countries in the far East that have occupied the world socio-economic affairs, had made attempts to improve the education system. The 6-3-3-4 system of Education was altered in favour of 9-3-4 system of education giving rise to a 9 - years Basic Education Programme, 3 years senior secondary, and 4 - years of university education. Presently, the 6-33-4 system of education is now changed to 9-3-4 system of education; this implies nine years of primary Education, three years of secondary Education and four years of university education respectively. These changes are all targeted towards improving the standard of education in Nigeria (Ambaliyu, 2008).

In all these changes, one of the reoccurring factors which have been a matter of great concern to policymakers, educators, and parents is the issue of poor achievement of students in the standard examinations conducted by external 
examination bodies like WAEC. Our present school system (9-3-4) has placed a high premium on the senior school certificate Examination. The certificate obtained is seen as a foundation for academic, political and economic progress in our society. Admissions into universities and job opportunities are based on some levels of performance of students in this standardized examination as conducted by WAEC and other examination bodies. The result of the senior school certificate examination can be used for academic planning and career choice; this indicates that the examination has far-reaching implications on the life of the examinees.

In this regard, the senior school certificate is a testimonial to one's ability and aptitude. Then, this examination has to be valid, reliable and usable as an evaluation instrument. All valid evaluation instruments are relatively reliable and usable however, not all reliable instruments may be valid; therefore, validity takes precedence over the other qualities possessed by good evaluation instruments. Validity is referred to as the extent to which a test instrument measures what it is designed to measure accurately. It is a concept that questions the relevance of a test. In affirmation, Ibe (2004) opined that an examination is invalid likewise the result if the items of the examination are not drawn from all the content areas of instruction. The representativeness of the course content by the items of the test should not only be in terms of coverage of topics but, it should reflect the categories of domains at which performances may be expected to occur. A test is said to be fair to all concerned, if it appraises both low and high cognitive ability; secondly, if the language of the test items is unambiguous and not open to several interpretations (Charles \& Brian, 2012).

Content validity refers to the extent to which the items on a test are fairly representative of the entire domain the test seeks to measure. One of the strengths of content validation is the simple and intuitive nature of its basic idea, which holds that what a test seeks to measure constitutes a content domain and the items on the test should sample from that domain in a way that makes the test items representative of the entire domain (Salkind, 2010). Content validity is the extent of a measurement tool represents the measured construct and it is considered as an essential evidence to support the validity of a measurement tool such as a questionnaire for research. Content validity is defined as the degree to which elements of an assessment instrument are relevant to and representative of the targeted construct for a particular assessment purpose (Yusoff, 2019). The purpose of content validation is to minimize the potential error associated with the instrument operationalization in the initial stages and to increase the probability of obtaining supportive construct validity in the later stages. Content validity helps the researcher gain invaluable feedback from panel of experts and develop and assess dimensions and subdimensions of the construct intended to be measured (Shrotrvia \& Dhanda, 2019). Ukwuije and Orluwene (2009) opined that content validation determines what proportion of the test items reflects the required content of the subject matter. The greater the percentage, the more content valid the test becomes and the smaller the percentage, the smaller content valid the test becomes (Kpolovie, 2010). Content validity measures the degree to which items of an instrument measure a 
representative sample of the subject matter content and the instructional objectives. Therefore, the questions that can be asked are: Do WAEC test items cover adequately what the students are expected to learn? Do they appraise appropriately the learning outcomes the students should exhibit with respect to the content, their relative weights with the levels of the cognitive skill as designed in the syllabus on Financial Accounting?

The teaching-learning process mainly involves the teacher and the students and the certification of the students is done by external examination bodies like WAEC. A different body prepares the Curriculum through the teachers and the examination bodies make inputs. The syllabus is developed by WAEC and the teachers who implement the curriculum do not participate adequately in developing the curriculum, and also in the certification of the students. However, the introduction of the continuous assessment in the school system has increased the teachers` participation in the evaluation but it is still doubtful if the records of the continuous assessment are incorporated in the summative examination result as conducted by WAEC.

There have been general outcries on the poor performance of Financial Accounting students in the senior school certificate examination as conducted by WAEC (WAEC 2018, chief examiners report in financial Accounting). Therefore, one wonders if the test items of the examination are drawn from what the students have been exposed to in the subject. Furthermore, a situation where a student rated below average by his/her teacher obtains a credit in an examination set by WAEC is also a course of concern to stakeholders in the education system such as teachers. In these regards, some pertinent questions such as: Do multiple-choice test items reflect the subject content? To what extents do WASSCE multiple-choice test items cover the various levels of objectives in the cognitive domain? To what extent are the cognitive behavioural outcomes of WASSCE multiple-choice test items representative of the content? In attempts to answer these questions, this study was necessitated. Generally, this study ascertained the content validity of WASSCE multiple-choice test item of Financial Accounting question papers for the periods of three years. Specifically, the study determined:

i. the extent to which the test items on the question papers are representatives of the various topics in the syllabus of Financial Accounting.

ii. the extent to which the spread of the test items on the question papers covered the various levels of the cognitive domain alongside the content area over the years of study.

The following research questions were posed to guide the study:

(i) To what extent are the WASSCE multiple-choice test items a representative sample of the content of Financial Accounting over the years of study?

(ii) To what extents are the WASSCE multiple-choice test items in Financial Accounting a representative sample of the cognitive behavioural objectives? 


\section{Hypotheses}

$\mathbf{H}_{01}$. The number of WASSCE multiple-choice test items in Financial Accounting drawn from the various topics is not significantly different from the number of questions expected to be drawn from them $(\mathrm{P}<0.05)$.

$\mathbf{H}_{02}$. The spread of the WASSCE multiple-choice items in Financial Accounting drawn in the various cognitive levels is not significantly different from the spread expected $(\mathrm{P}<0.05)$.

\section{Materials and Methods}

\subsection{Research Design}

The design employed in this study is the analytic survey research design. Analytic survey research according to Asim, Idaka and Eni (2017) involves the identification and interpretation of data already existing in documents, pictures and artifacts. The design is considered appropriate because the researchers collected and analysed data already existing in documents. This study used the WASSCE financial accounting question papers administered in Nigeria. The population of this study includes all the 150 multiple-choice question papers in Financial Accounting set by West African Examination Council. The sample of the study comprised all the multiple-choice questions (May/June) in West African Senior School Certificate Examination conducted by WAEC from 20162018. The study employed purposive sampling technique. The purposive sampling techniques was used for the study because only the more recent WAEC Financial Accounting question papers were purposively selected to ensure current coverage over time.

\subsection{Reliability of the Instrument}

One hundred and fifty (150) objective questions comprising fifty (50) questions from each year were tabulated and given to three experts in measurement and evaluation for classification. The researchers' own classification was also compared to that of the experts. The inter-rater reliability coefficient between the researchers' classification and that of the experts were also calculated; the values obtained were 0.89 and 0.91 respectively using Kendal's Coefficient of Concordance. Each multiple-choice test item on the question papers were assessed by some experts to indicate the levels of cognitive domains which they belong to and also the topics to which the items belong to. The researchers assigned weights to the topics in the curriculum for Financial Accounting based on the emphasis placed on each topic by the curriculum. This emphasis depends on how broad a topic is, with respect to the number of weeks spent teaching each topic. The researchers adopted the provisions of the scheme of work on financial accounting for higher secondary schools where weeks expected to teach each topic were specified.

Thus, the researchers calculated the number of weeks allotted to each topic by the scheme of work. The number of weeks assigned to a particular topic was converted to the proportion of the total number of weeks used in teaching all the topics in the curriculum expressed in terms of the 150 questions involved in the study. The value obtained is the expected weight of the topic required to be tested by the WASSCE (May/June) Financial Accounting. 
The researchers also classified the entire behavioural objectives stated in the curriculum for financial accounting against the cognitive levels they tested. Thus, the sum of a particular cognitive level was converted to the proportion of the total number of all the cognitive levels emphasized in the curriculum expressed in terms of the 150 questions involved in the study. The value obtained is taken as the expected weight of the cognitive level required to be tested by the WASSCE (May/June) Financial Accounting.

\subsection{Method of Data Analysis}

Finally, each question in the WASSCE (May/June) Financial accounting question papers was classified by the researchers against the particular level of the cognitive domain it tested. The sum of a particular cognitive level is therefore the observed weight of that cognitive level tested by WASSCE (May/June) Financial Accounting over the three years. Chi-square was used to test the significant difference at $(\propto<0.05)$ from the observed frequency result. The extent of the content coverage was determined using percentages.

\section{Results}

Table 1: Number of questions and percentage spread in WASSCE Financial Accounting question papers from 2016 to 2018

\begin{tabular}{|c|c|c|c|c|c|c|c|}
\hline \multirow[t]{3}{*}{$\mathbf{S} / \mathbf{N}$} & \multirow{3}{*}{$\begin{array}{l}\text { Topics in the Core Curriculum } \\
\text { For Financial Accounting }\end{array}$} & \multicolumn{6}{|c|}{ Number of Questions and Percentages } \\
\hline & & \multicolumn{2}{|c|}{2016} & \multicolumn{2}{|c|}{2017} & \multicolumn{2}{|c|}{2018} \\
\hline & & $\begin{array}{c}\text { No. of } \\
\text { Qs. }\end{array}$ & $\begin{array}{l}\% \text { of } \\
\text { Qs. }\end{array}$ & $\begin{array}{c}\text { No. of } \\
\text { Qs. }\end{array}$ & $\begin{array}{l}\% \text { of } \\
\text { Qs. }\end{array}$ & $\begin{array}{c}\text { No. of } \\
\text { Qs. }\end{array}$ & $\begin{array}{c}\% \text { of } \\
\text { Qs. }\end{array}$ \\
\hline 1 & Introduction & 0 & 0 & 0 & 0 & 0 & 0 \\
\hline 2 & $\begin{array}{l}\text { Principles and practice of } \\
\text { double-Entry }\end{array}$ & 10 & 20 & 12 & 24 & 9 & 18 \\
\hline 3 & The final accounts of sole trader & 11 & 22 & 5 & 10 & 2 & 4 \\
\hline 4 & Reserves and provisions & 3 & 6 & 2 & 4 & 7 & 14 \\
\hline 5 & Manufacturing Accounts & 3 & 6 & 3 & 6 & 6 & 12 \\
\hline 6 & $\begin{array}{l}\text { Control accounts and self- } \\
\text { balancing ledger }\end{array}$ & 7 & 14 & 5 & 10 & 6 & 10 \\
\hline 7 & $\begin{array}{l}\text { Single-entry and incomplete } \\
\text { records }\end{array}$ & 1 & 2 & 1 & 2 & 0 & 0 \\
\hline 8 & $\begin{array}{l}\text { Accounts of nonprofit making } \\
\text { organization }\end{array}$ & 2 & 4 & 1 & 2 & 2 & 4 \\
\hline 9 & $\begin{array}{l}\text { Accounting concepts and } \\
\text { convention }\end{array}$ & 3 & 6 & 3 & 6 & 2 & 4 \\
\hline 10 & Partnership & 3 & 6 & 3 & 6 & 2 & 4 \\
\hline 11 & Company's account & 4 & 8 & 7 & 14 & 7 & 14 \\
\hline 12 & $\begin{array}{lll}\text { Departmental and Branch } \\
\text { Account }\end{array}$ & 0 & 0 & 3 & 6 & 1 & 2 \\
\hline 13 & Public Sector Accounting & 1 & 2 & 3 & 6 & 4 & 8 \\
\hline 14 & Introduction to Data processing & 2 & 4 & 2 & 4 & 3 & 6 \\
\hline & Total & 50 & 100 & 50 & 100 & 50 & 100 \\
\hline
\end{tabular}

Qs $=$ Questions 
Table 1 above shows the number of questions and percentage derived from each topic for the three years under review.

A close observation of Table 1 shows that:

a) In the year 2016, the principles and practices of double-entry, final accounts of a sole trader, control accounts and self-balancing ledger and company's accounts were emphasized more.

b) The trend was also observed in 2017 and 2018. In 2017, the numbers of questions from the respective topics were 12, 5, 5 and 7 while in 2018 the numbers of questions from each topic were 9, 2, 6 and 7 respectively.

c) In 2016, no question was derived from departmental account and branch account respectively.

d) For the years under review, WAEC did not test students in introduction to financial accounting. This accounted for the $0 \%$ shown in the table.

e) Emphases were placed only on four topics: Principles of double-entry, final Accounts, control accounts and self-balancing ledger and company's account with $20 \%, 22 \%, 14 \%$ and $8 \%$ respectively.

f) In 2018, the final account of sole trader had $4 \%$ which is a deviation from 2016 and 2017 respectively.

Table 2: Number of questions expected and observed from each topic

\begin{tabular}{|l|l|c|c|}
\hline S/N & \multicolumn{1}{|c|}{ Topics } & $\begin{array}{c}\text { Number of } \\
\text { questions according } \\
\text { to scheme } \\
\text { (Expected) }\end{array}$ & $\begin{array}{c}\text { Number of } \\
\text { questions } \\
\text { observed } \\
\text { (WASSCE) }\end{array}$ \\
\hline 1 & Introduction to Financial Accounting & 8 & 0 \\
\hline 2 & $\begin{array}{l}\text { Principles and practice of double- } \\
\text { entry }\end{array}$ & 13 & 31 \\
\hline 3 & The final account of sole trader & 12 & 18 \\
\hline 4 & Reserves and provisions & 13 & 12 \\
\hline 5 & Manufacturing accounts & 13 & 12 \\
\hline 6 & Control accounts & 10 & 17 \\
\hline 7 & Single-entry and incomplete records & 7 & 2 \\
\hline 8 & $\begin{array}{l}\text { Accounts of nonprofit making } \\
\text { organization }\end{array}$ & 7 & 8 \\
\hline 9 & Accounting concepts and convention & 8 & 8 \\
\hline 10 & Partnership & 15 & 4 \\
\hline 11 & Company's account & 17 & 8 \\
\hline 12 & Departmental accounts & 10 & 7 \\
\hline 13 & Public sector accounting & 150 & 150 \\
\hline 14 & Introduction to data processing & & 5 \\
\hline & Total &
\end{tabular}

The results in Table 2 showed that:

1. Questions were not drawn from introduction to accounting for the years as against 8 questions which are the number of questions expected to be drawn from the topic.

2. Topic 2: principles and practice of double-entry attracted 31 questions as against 13 based on the weight assigned to the topic in the scheme of work. 
3. The number of questions expected from topics $4,5,11$, and 13 were not significantly different from the numbers of questions observed.

4. For Topic 9 and 14, the number of questions expected were also the same as the numbers of questions observed from the question paper.

5. A difference was observed from the numbers of questions expected as against the numbers of questions observed in topics 3, 6, 7, 10 and 12 .

Table 3: Number of questions derived from each cognitive level for the three years

\begin{tabular}{|l|l|c|c|c|c|c|c|}
\hline \multirow{2}{*}{ S/N } & \multirow{2}{*}{ Cognitive Levels } & \multicolumn{2}{|c|}{$\mathbf{2 0 1 6}$} & \multicolumn{2}{c|}{$\mathbf{2 0 1 7}$} & \multicolumn{2}{c|}{$\mathbf{2 0 1 8}$} \\
\cline { 3 - 8 } & & $\begin{array}{c}\text { No. of } \\
\text { Qs }\end{array}$ & $\begin{array}{c}\text { \% of } \\
\text { Qs }\end{array}$ & $\begin{array}{c}\text { No. of } \\
\text { Qs }\end{array}$ & $\begin{array}{c}\text { \% of } \\
\text { Qs }\end{array}$ & $\begin{array}{c}\text { No. of } \\
\text { Qs }\end{array}$ & $\begin{array}{c}\text { \% of } \\
\text { Qs }\end{array}$ \\
\hline 1 & Knowledge & 9 & 18 & 13 & 26 & 26 & 52 \\
\hline 2 & Comprehension & 14 & 28 & 11 & 22 & 8 & 16 \\
\hline 3 & Application & 17 & 34 & 17 & 34 & 12 & 24 \\
\hline 4 & Analysis & 4 & 8 & 3 & 6 & 3 & 6 \\
\hline 5 & Synthesis & 3 & 6 & 2 & 4 & 1 & 2 \\
\hline 6 & Evaluation & 3 & 6 & 4 & 8 & 0 & 0 \\
\hline & Total & 50 & 100 & 50 & 100 & 50 & 100 \\
\hline
\end{tabular}

Qs $=$ Questions

Table 3 above showed that:

a) In 2016, 2017 and 2018 the numbers of questions from knowledge level were 9,13 and 26 respectively.

b) The students were tested at comprehension level in 2016, 2017 and 2018 with 14,11 and 8 questions respectively out of 50 questions for each year.

c) For the three years under review, much emphasis was placed on knowledge, comprehension and application.

d) There was a consistent trend as analysis in 2016, 2017 and 2018 had 4, 3 and 3 questions drawn from that level within the three years under review.

e) Synthesis and evaluation were less emphasized as shown in the table with synthesis having 3, 4 and 0 , in the three respective years.

A close observation of Table 3 shows that WASSCE multiple-choice test items for the three years had many questions from knowledge, comprehension and application level. In 2016, $18 \%$ of questions were drawn from knowledge, $28 \%$ from comprehension while $34 \%$ arose from application compared to $8 \%, 6 \%$ and $6 \%$ for items on analysis, synthesis and evaluation respectively. The same trend was repeated in 2017 when knowledge, comprehension and application got $26 \%$, $22 \%$ and $34 \%$ respectively compared to analysis, synthesis and evaluation that had $6 \%, 4 \%$ and $8 \%$ items respectively. In 2018, the same was also observed with knowledge, comprehension and application getting 52\%, 16\% and $24 \%$ respectively while analysis, synthesis and evaluation was $6 \%, 2 \%$ and $0 \%$ respectively. This means that questions were not drawn from evaluation level of cognitive domain in 2018. 
Table 4: Number of Questions Expected from each Cognitive Level as against the Observed Number

\begin{tabular}{|l|l|c|c|}
\hline S/N & \multicolumn{1}{|c|}{ Cognitive levels } & $\begin{array}{c}\text { Number of questions } \\
\text { expected from each } \\
\text { cognitive level }\end{array}$ & $\begin{array}{c}\text { Number of questions } \\
\text { observed from each } \\
\text { cognitive level }\end{array}$ \\
\hline 1 & Knowledge & 23 & 48 \\
\hline 2 & Comprehension & 37 & 33 \\
\hline 3 & Application & 30 & 46 \\
\hline 4 & Analysis & 37 & 10 \\
\hline 5 & Synthesis & 15 & 6 \\
\hline 6 & Evaluation & 8 & 7 \\
\hline & Total & 150 & 150 \\
\hline
\end{tabular}

Table 5: Summary of Chi-square analysis for weights of topics in the Financial Accounting curriculum and in WAEC syllabus

\begin{tabular}{|c|c|c|c|c|c|c|}
\hline $\mathbf{S} / \mathbf{N}$ & Topics & $\begin{array}{l}\text { Weights } \\
\text { of topics } \\
\text { by } \\
\text { scheme of } \\
\text { work (E) }\end{array}$ & $\begin{array}{l}\text { Weights of } \\
\text { topics by } \\
\text { numbers of } \\
\text { questions } \\
\text { (O) }\end{array}$ & O-E & $(\mathrm{O}-\mathrm{E})^{2}$ & $\frac{(\mathrm{O}-\mathrm{E})^{2}}{\mathrm{E}}$ \\
\hline 1 & Introduction & 8 & 0 & -8 & 64 & 8.00 \\
\hline 2 & $\begin{array}{l}\text { Principles and practice } \\
\text { of double-entry }\end{array}$ & 13 & 31 & 18 & 324 & 24.92 \\
\hline 3 & $\begin{array}{l}\text { The final accounts of } \\
\text { sole trader }\end{array}$ & 12 & 18 & 6 & 36 & 3.00 \\
\hline 4 & $\begin{array}{ll}\text { Reserves } & \text { and } \\
\text { provisions } & \end{array}$ & 13 & 12 & -1 & 1 & 0.08 \\
\hline 5 & $\begin{array}{l}\text { Manufacturing } \\
\text { accounts }\end{array}$ & 13 & 12 & -1 & 1 & 0.08 \\
\hline 6 & $\begin{array}{l}\text { Control accounts and } \\
\text { self-balancing ledger }\end{array}$ & 10 & 17 & 7 & 49 & 4.9 \\
\hline 7 & $\begin{array}{l}\text { Single-entry and } \\
\text { incomplete records }\end{array}$ & 7 & 2 & -5 & 25 & 3.57 \\
\hline 8 & $\begin{array}{l}\text { Accounts of nonprofit } \\
\text { making organization }\end{array}$ & 7 & 5 & -2 & 4 & 0.57 \\
\hline 9 & $\begin{array}{l}\text { Accounting concepts } \\
\text { and convention }\end{array}$ & 8 & 8 & 0 & 0 & 0 \\
\hline 10 & Partnership & 15 & 8 & -7 & 49 & 3.27 \\
\hline 11 & Company's account & 17 & 18 & 1 & 1 & 0.06 \\
\hline 12 & $\begin{array}{ll}\text { Departmental } & \text { and } \\
\text { branch account } & \end{array}$ & 10 & 4 & -6 & 36 & 3.6 \\
\hline 13 & $\begin{array}{ll}\text { Public } & \text { sector } \\
\text { accounting } & \end{array}$ & 10 & 8 & -2 & 4 & 0.4 \\
\hline 14 & $\begin{array}{l}\text { Introduction to Data } \\
\text { processing }\end{array}$ & 7 & 7 & 0 & 0 & 0 \\
\hline & Total & 150 & 150 & & & 52.45 \\
\hline
\end{tabular}


The result revealed the fact that the calculated $X^{2}(52.45)$ is greater than the tabulated $X^{2}$ of 22.36 at 0.05 level of significance and degrees of freedom (df) of 13. Since the calculated value of $X^{2}=52.45$ is greater than the tabulated value of 22.36; the null hypothesis which state that the number of WASSCE multiple-choice test items in Financial Accounting drawn from the various topics is not significantly different from the number of questions expected to be drawn from them is therefore, rejected. The implication of this is that there is a significant difference between the weights assigned to the topics in the curriculum for financial accounting to the weights assigned by West African Examination Council (multiple-Choice Items) from 2016-2018.

Table 6: Summary of Chi-Square Weights Assigned to the levels of Cognitive domain in the Curriculum and the Weights Assigned to them by West African Examination Council Financial Accounting

\begin{tabular}{|l|l|c|c|c|c|c|}
\hline S/N & Cognitive Levels & $\begin{array}{c}\text { Expected } \\
\text { Weights } \\
\mathbf{E}\end{array}$ & $\begin{array}{c}\text { Observed } \\
\text { Weights } \\
\text { O }\end{array}$ & O-E & $\mathbf{( O - E )}^{2}$ & ${\frac{(\mathbf{O}-E)}{\mathbf{E}^{2}}}$ \\
\hline 1 & Knowledge & 23 & 48 & 25 & 625 & 27.17 \\
\hline 2 & Comprehension & 37 & 33 & -4 & 16 & 0.43 \\
\hline 3 & Application & 30 & 46 & 16 & 256 & 8.53 \\
\hline 4 & Analysis & 37 & 10 & -27 & 729 & 19.70 \\
\hline 5 & Synthesis & 15 & 6 & -9 & 81 & 5.4 \\
\hline 6 & Evaluation & 8 & 7 & -1 & 1 & 0.13 \\
\hline & & 150 & 150 & $\mathrm{X}^{2}$ & $=$ & 61.36 \\
\hline
\end{tabular}

The results showed that, the calculated value of 61.36 is greater than the tabulated value of 11.07 at 0.05 level of significance and degrees of freedom (df) of 5. This implies that, there is a significant difference between the spread of the WASSCE multiple-Choice Items in financial accounting drawn in the various cognitive levels from the spread expected. The null hypothesis which state that the spread of the WASSCE multiple-choice items in Financial Accounting drawn in the various cognitive levels is not significantly different from the spread expected is thus, rejected at 0.05 level of significance with degrees of freedom of 5 . This means that, there is significant difference from the spread expected in the various cognitive levels.

\section{Discussion}

In the WAEC syllabus, there are 14 topics. These 14 topics were spread over three years in the scheme of work. The weight assigned to each topic is based on the numbers of weeks used in teaching the topic. This is in line with the view of Gronlund (1976) opined that the weights of topics should depend on personal judgment as guided by the amount of time devoted to each topic during instructions. In view of the above, the numbers of questions expected from each topic and the numbers of questions drawn from each topic for the three years under review are shown in Table 2. The number of questions expected from topic 1; that is, from "introduction" are 8 questions, whereas no question was drawn from the topic. In topic 2, 13 questions were expected while 31 questions were drawn from the topic. Topic 3-the final Account of sole trader attracted 18 
questions as against 12 questions expected. This trend was also observed in topics 6 - control accounts, 7-single-entry and incomplete records, 10partnership account and 12-departmental accounts. The variation between the expected and observed in the above topics was significantly different. These findings agreed with the result of other researchers such as, Offor (2001), Ibe (2004), Amajuoyi (2004) and Nwana (2007).

The findings revealed that topic 4-reserves and provisions, 5-manufacturing accounts, 8 - accounting of nonprofit making organization, 11 - company's account and 13 - public sector accounting, the numbers of questions expected from these topics were not significantly different from the numbers drawn. For topic 4, 13 questions were expected while 12 questions were drawn; topic 5manufacturing account, 13 questions were also expected but 12 were drawn; topic 8-accounts of nonprofit making organizations, 7 questions were expected while 5 were drawn. Also, in topics 11 and 13 - company's account and public sector accounting, 17 and 10 were expected respectively while 18 and 8 were observed. Co-incidentally, in topics 9; 14 accounting concepts and conventions and introduction to data processing, 8 and 7 questions were expected and 8 and 7 questions were drawn respectively.

Table 3 presented the number of questions observed from each cognitive level for the three years. In 2016, out of the total of 50 questions, 9 came from Knowledge, 14 from Comprehensive, 17 from Application while Analysis, Synthesis and Evaluation got 4, 3 and 3 respectively. In 2017, Knowledge, Comprehension and Application got 13, 11 and 17 respectively while Analysis, Synthesis and Evaluation were 3,2 and 4. This trend also was observed in 2018 where Knowledge, Comprehension and Application were given priority with 26, 8 and 12 with less emphasis on Analysis, Synthesis and Evaluation having 3, 1 and 0 respectively. This finding is in agreement with the study of Buba and Kojigili (2020) which reported that performance objectives were highest at the comprehension level of cognitive domain followed by application and knowledge levels.

The result of the study revealed that Knowledge level got $18 \%, 26 \%$ and $52 \%$ for three years under review. Comprehension got 28\%, 22\% and 16\% for 2016, 2017 and 2018. At Application level for 2016, 2017 and 2018, the percentages were 34, 34 and 24 respectively. The findings also show 8\%, 6\% and 6\% for Analysis level for the three years. Synthesis and Evaluation got 6\% respectively for 2016. In $2017,4 \%$ and $8 \%$ while in 2018 it was $2 \%$ and $0 \%$ respectively. This finding is in agreement with the finding of Buba and Kojigili (2020) who found out that comprehension level of cognitive domain has the highest percentage followed by application and knowledge. The other three levels of cognitive domain have percentage spread decreasing as they go to higher levels.

Table 4 presented an overview of the numbers of questions expected from each level and the numbers of questions observed. This is very pertinent in answering research question 2. The number of questions expected from knowledge for the three years is 23 while 48 was observed, for Comprehension, the questions 
expected is 37 while 33 was observed; for Application 30 questions were expected while 46 questions were observed; for the higher levels of Analysis, Synthesis and Evaluation, 37, 15 and 8 questions were expected but we observed questions were 10, 6 and 7 respectively. This implies that the Knowledge and Application levels were overemphasized; Analysis and Synthesis were underemphasized while the coverage on Knowledge and Evaluation has a pass mark.

The spread of the WAEC multiple-choice items in Financial Accounting drawn in the various cognitive levels is not significantly different from the spread expected $(\mathrm{P}<0.05)$. The result clearly shows that some levels were overemphasized while others were underemphasized. Knowledge and Application levels were overemphasized while analysis and synthesis were underemphasized. Comprehension and Evaluation were fairly tested. This finding agrees with the findings of Ijeoma, Eme and Nsisong (2013) who found that some topics were overemphasized and others underemphasized in WASSCE chemistry question from 1999-2002.

The results of the finding revealed that WAEC did not maintain the weights assigned to levels in the Financial Accounting Curriculum and the scheme of work. There was a significant difference in the various cognitive levels from the spread expected. This shows that WAEC Financial Accounting questions have low content validity. This result corroborated with Nwana (2007) and, Dike (1998). In their work, they confirmed that WAEC tests possessed low degree of content validity. This is in line with the findings of Nwana, Onah and Nwokenne (2012) who opined that teachers predominantly test lower levels of the cognitive domain and ignores the higher levels. At secondary school level of education, students are supposed to be tested more at the higher levels of cognitive domain. This view is supported by Nwana (2007: 47) who opined that "if the examination is knowledge-centered, the students will tend to study the subject for its factual content and pay little or no attention to understanding these facts, ideas etc., applying them in novel situations, analyzing them into new wholes and evaluating them, then the examination evaluates subject being examined". The exposition of the students to the higher-level of cognitive domain is beneficial to the students as postulated by Grossman (1971). The predominant use of high-level questions is an effective way of trying to move the students forward with high and low understanding but low questions strategy will not facilitate high-level understanding.

The study prominently shows that some topics were not adequately covered while some other topics were overemphasized. Only few topics were fairly tested. The topic "introduction to accounting" was not tested at all. Principles and practice of double-entry was overemphasized, same as the final account of sole proprietors, control accounts and self-balancing ledger. Some of the topics underemphasized include - single-entry and incomplete records, partnership, departmental and branch accounts. While WAEC needs to be commended on their efforts in some topics such as reserves and provisions, manufacturing accounts, accounting concepts and conventions, company's account, public 
sector accounting and introduction to data processing, these topics were fairly tested.

When emphasis is much on some topics over a period of time and less emphasis on others, this constitutes a danger to the Educational sector as students and teachers will concentrate on areas with high emphasis. WAEC being the leading examination body in West Africa is expected to set a standard that others can follow. This is because, when any of the above complications happens, it will have a triple implication in the society (1) to the Education system as a whole (2) to the teacher; and (3) to the students. When some topics are overemphasized, the implication is that the teachers will direct all their efforts toward those topics; this encourages laziness among the teachers as they already know the areas of concentration. This system also affects the students' attitude to study. They only concentrate on few topics and anytime there is a deviation, their performance level will drop. To the educational system, this pattern of overemphasizing or underemphasizing on some topics is very dangerous because students who passed through such turnout to be half baked. This is in agreement with Nwana (2007) who opined that teachers tend to emphasize the importance of those topics which reoccur in examinations, and students tend to study those topics which reoccur in examinations and leave out those which do not, even if these topics appear on the prescribed syllabus. In view of the above, one can equally state that the poor performance of students in Financial Accounting within the period under review might not solely be as a result of ignorance of the students but also be largely attributed to error in test designs. Nwana (2007) rejected the idea of setting questions on only few topics from the syllabus. The author opined that setting questions on a section of the syllabus means that the examination will only favour those pupils who by chance concentrated on those restricted areas. The others would appear failures. Here, it is shown clearly that the examination is at fault and not the pupils/students.

\section{Conclusion}

Findings within the periods under review show that the WASSCE Financial Accounting multiple-choice test items have a low content validity. For a child to achieve all-round-education, effective implementations of the curriculum content have to be administered. This can only be achieved by well qualified and dedicated teachers with the provisions of adequate instructional materials to effect changes in the behaviours of the learners. The WAEC examiners most probably did not use test blueprint in developing the entire examination tests they used in examining the students in financial accounting for the three years under study. This is evident as the distribution of the questions did not reflect or represent proportionally the topics contained in the curriculum for financial accounting. Also the various levels of the cognitive domain were not proportionately tested either. Some topics and levels of cognitive domains were overemphasized while some were underemphasized. Therefore, the WASSCE questions 2016 to 2018 in financial accounting have a very low degree of content validity. West African Examination Council should insist on their chief examiners using a table of specification in order to master the weights attached 
to the content areas as indicated in the senior secondary school curriculum in financial accounting

\section{Implication of the Study}

When some topics are overemphasized, the implication is that the teachers will direct all their efforts toward those topics; this encourages laziness among the teachers as they already know the areas of concentration. This system also affects the students' attitude to study. They only concentrate on few topics and anytime there is a deviation, their performance level will drop. This might be as a result of WAEC not using table of specification and the non-involvement of experts in the selection of questions from their question bank or in the constructions of questions. WAEC examiners should be made to understand through training, workshops, seminars and conferences the implication of over-emphasising and under-emphasising some topics and lower cognitive levels when generating questions.

\section{Acknowledgments}

We are deeply grateful to all our colleagues who assisted in this study and all the authors whose works were consulted during the process of this study.

\section{References}

Adewuyi, J. O, \& Oluokun, O. O. (2001). Introduction to test and measurement in education. Oyo: Odumatt Press.

Akinbolati, K. B. (2003). Teacher's and learner's factors as determinants of senior secondary school student's achievement in school certificate Mathematics (Unpublished master's thesis). University of Ibadan, Ibadan.

Alimi, O. S., Ehinola, G. B, \& Alabi, F. O. (2012). School types, facilities and academic performance of students in secondary schools in Ondo State, Nigeria. International Education Studies, 5(3). https://doi.org/10.5539/ies.v5n3p44

Amadi, K. K. (2002). Theory and practice of financial accounting. Owerri: Joe Mankpa Publishers.

Amajuoyi, I. J. (2004). Content validity of May/June West African Senior School Certificate Examination Questions in Chemistry 1999-2002 (Unpublished master's thesis). University of Port Harcourt, Port Harcourt.

Ambaliyu, A. O. (2008). Availability and utilization of material resources as correlates of students learning outcomes in secondary school chemistry (Unpublished doctoral dissertation). University of Ibadan, Ibadan.

Asaolu, A. (2002). Modern book-keeping and accounts. Ibadan: Calabeks publishers.

Asim, A. E., Idaka, I. E., \& Eni, E. I. (2017). Research in education: Concepts and Techniques. Calabar: Bloann Educational Publishers

Bob, K. (2012). Measurement, assessment, and evaluation in education. Retrieved from http://www.adprima.com/measurement.htm

Buba, M. A, \& Kojigili, S. T. (2020). Content validation of basic education certificate examination questions in basic science in Adamawa State, Nigeria. Journal of Education, Society and Behavioural Science, 33(2), 42-54. https://doi.org/10.9734/JESBS/2020/v33i23020

Charles, S., \& Brian, D. (2012). Handbook on measurement, assessment, and evaluation in higher education. New York: Taylor and Francis Publishers. https://doi.org/10.4324/9780203142189 
Chinweike, O. (2011). Definition of accounting/modern business perspective. Retrieved May 15, 2020 from http://www.accountantnextdoor.com/definition-modernbusiness-perspective.pdf

Dike, H. I. (1998). Evaluation of Educational Programmes: Needs Analysis, Formative Evaluation and Summative Evaluation. Port Harcourt: Paragraphics.

Donna, G. B. (2011). Testing anxiety: researchers find solution to help students cope. Retrieved May 27, 2020 from www.huffingtonspot.com

Eneja, R. U. (2013). Influence of cognitive ability, gender and location on students' achievement in senior secondary school financial accounting (Unpublished master's thesis). University of Nigeria, Nsukka.

Federal Republic of Nigeria. (2014). National policy on education (4th ed.). Lagos: NERDC press.

Gronlund, N. E. (1976). Measurement and evaluation in teaching. New York: Macmillan Publishing Co. Inc.

Grossman, A. S. (1971). Mid-nineteenth century methods for the 1970s; The arithmetic teacher. California: Jossey-Bass.

Ibe, H. N. (2004). Content validity of WAEC and NECO multiple-choice test item in biology (2003-2004).

Igben, R. O. (2009). Financial accounting made simple (3rd ed.). Lagos: Roi Publishers.

Ijeoma, J. A., Eme, U. J, \& Nsisong, A. U. (2013). Content validity of May/June, West African Senior school certificate examination (WASSCE) questions in chemistry. Journal of Education and Practice, 4(7), 15-21.

Illeris, K. (2014). Transformative learning in the perspective of a comprehensive learning theory. Journal of Transformative Education, (2), 79-89. https://doi.org/10.1177/1541344603262315

Kpolovie, P. J. (2010). Advanced research methods. Owerri: Springfield Publishers Ltd.

Nigerian Educational research and development council. (2007). Senior Secondary Education Curriculum: Financial accounting for ss1-3. Abuja: NERDC.

Nwana, O. C. (2007). Educational measurement and evaluation. Owerri: Bamaway Publishers.

Nwana O. C, Onah, F. E, \& Nwokenne N. O. (2012). Content validity of junior secondary school certificate examination questions in Business Studies. Journal of Science and Computer Education, 2(1), 18-27.

Obidile, J. I., Amobi, S. C., Uzoekwe, H. E., \& Akuezilo, J. A. (2017). Perceived factors influencing academic performance of students in accounting in secondary schools in Anambra State. Journal of Humanities and Social Science (IOSR-JHSS), 22(2), 96-99. https://doi.org/10.9790/0837-2202039699

Offor, C. (2001). Content validity of Senior School Certificate Examination (SSCE) Chemistry (Unpublished master's thesis). Imo State University, Owerri.

Okereke L. C. (2000). Managerial accounting and control (A professional approach). Owerri: Joe Mankpa's Publishers.

Oparaku, D. D. (2005). Examination malpractice: The Nigerian Experience. Owerri: John Diwe Press.

Salkind, N. J (2010). Research methods. Sage Publications. https://dx.doi.org/10.4135/9781412961288.n74

Shrotryia, V. K, \& Dhanda, U. (2019). Content Validity of Assessment Instrument for Employee Engagement. SAGE Open, 1-7. https://doi.org/10.1177/2158244018821751

Thorndike, R. L., \& Hagen, E. P. (1976). Measurement and evaluation in psychology and education. New York: John Wiley and Sons Inc. 
Ukwuije, R. P. I., \& Orluwene, G. W. (2009). Validity of educational measurement. In O.C Nwana (Ed.), Educational measurement and evaluation. Onitsha: Ark Publishers.

Uwameiye, R., \& Ogunbameru, M. T. (2005). A comparative analysis of two methods of teaching financial accounting at secondary schools.

West African Examination Council. (2018). Chief examiners report: May/June West African senior school certificate examination. Lagos: WAEC.

Yusoff M. S. B, (2019). ABC of content validation and content validity index calculation. Education in Medicine Journal, 11(2), 49-54. https://doi.org/10.21315/eimj2019.11.2.6 